\title{
THE RECEPTION OF PETER SINGER'S THEORIES IN FRANCE
}

\author{
EMILIE DARDENNE \\ (Université de Rennes II - France)
}

\begin{abstract}
Peter Singer's views on the status of animals, the sanctity of human life, and world poverty have attracted both attention and intense controversy in many Western countries, including the United States, Canada, and Germany. The reactions in France to his theories are less well-known. The purpose of this paper is to present an overview of critical responses to Singer by French academics and thinkers. How have they received Singer's contention that we must bring nonhuman animals within the sphere of moral concern? How has his claim been received according to which we must recognize that the worth of human life varies? Do French scholars agree with his utilitarian views on abortion, euthanasia, infanticide, his definition of the term "person"? Finally, is he considered in France as a brilliant and groundbreaking ethicist, as a dangerous extremist, or somewhere in between?

Key-words:
\end{abstract}

\section{Introduction}

Peter Singer is often introduced as one of the most influential philosophers alive. He is today's foremost utilitarian. His books, translated in twenty languages, include several international best-sellers including Animal Liberation (1975), Practical Ethics (1979), Rethinking Life and Death (1994), One World (2002). His work played a major role in establishing the animal rights movement and has significantly contributed to debate in the field of bioethics.

$\mathrm{He}$ is also seen as a rather unorthodox thinker, regarding his views on the status of animals. His tenet that the interests of all beings capable of suffering should be worthy of equal consideraton, whatever their species has been widely denounced for denying the sanctity of human lives. In 1999, his defence of euthanasia and infanticide for severely disabled human beings drew fire notably in Germany, Switzerland, and Austria. His appointment by Princeton as Professor of Bioethics unleashed intense debates.

Though French versions of his major books have been published in France, reactions to his theories are little known. They come mainly from three sectors as detailed below:

1. Philosophers of the continental school like Luc Ferry and Élisabeth de Fontenay who rely on humanism and Kantian deontology.

2. Christian thinkers, like Paul Valadier.

3. The French animal liberation movement, with prominent figures such as Yves Bonnardel and Estiva Reus.

Major issues raised are to Singer's inclusion of nonhuman animals within the sphere of 
moral concern, his claim that the value of human life is not an absolute, and his utilitarian views on suffering, abortion, euthanasia, or infanticide. Do they make him a dangerous extremist, a brilliant and groundbreaking ethicist, or a little of both? The reactions of the French thinkers enumerated above will be examined in this paper.

\section{The Humanist Tenet and Kantian Deontology}

\section{1. Luc Ferry ${ }^{l}$ and Liberty}

Ferry is one of the critics of Singer's theories from a continental philosophical perspective. In a series of articles published in the academic journal Le Débat he takes issue with Singer's demand formulated in his and Cavalieri's "Great Ape Project," that the fundamental rights of gorillas, chimpanzees and orang-utans be written into our constitutions. Ferry claims that apes cannot have rights, but that humans have duties towards them. Utilitarians therefore err, according to him, especially with regard to their definition of beings included into, or excluded from, our moral world. Singer and Cavalieri evoke such criteria as reason, language and species as the traditional bases on which our ethical system has been built. Liberty, which Ferry claims to be the mainstay of continental philosophy, is left out. Yet for Ferry a moral being is first and foremost defined by "his liberty, conceived as a faculty to force himself out of the idiosyncratic, natural and historical determinisms which weigh heavy on all natural (premoral) life forms," (2000: 164) a reality Singer is said to misinterpret and caricature. It was left to Paola Cavalieri to defuse the debate by simply pointing out that the essential element in Kantian tradition is reason, not liberty, and that liberty merely derives from reason (2000: 184).

Marginal cases offer a second bone of contention. According to this utilitarian argument, animals find themselves promoted into our moral world where theoretically all humans are included, even marginal humans who share so-called animals" "deficiencies." Is it a levelling up of animals which are brought into the moral world of humans or rather a levelling down of newborn children, patients in a deep coma, the severely handicapped? Utilitarians like Singer and Cavalieri hold that animals with similar levels of self-consciousness or autonomy as humans should be treated in the same way, and be granted the same fundamental rights. Ferry rejects this argument because newborn children, comatose patients and the severely handicapped will one day cease to be such marginal humans, or might cease to be so, or might not have become such passive citizens whereas a chimpanzee will always remain a chimpanzee, precluding any kind of ethical reciprocity. It seems impossible to ignore this dichotomy. But how can Ferry build an argument on a potential prenatal state or worse on a potential state which existed before conception? It seems irrational to define a moral status not on real characteristics but on the characteristics that a being possessed, might have 
possessed or might potentially one day possess.

The problem with Ferry is that he views Singer's theories as a sort of hatred of humankind, rather than as the formulation of a new rational ethic, in response to recent scientific discoveries and to greater awareness of the kinship between humans and animals. Singer's rationale may be argued with, but probably not from Ferry's angle of reasoning.

Élisabeth de Fontenay, who writes in the same journal another critical response to the Great Ape Project, provides a more stimulating contention.

\section{2. Élisabeth de Fontenay: ${ }^{2}$ Singer's Astounding "Misanthropy"}

In her most recent book, ${ }^{3}$ Élisabeth de Fontenay criticizes the naivety of opponents to the sanctity of human life ethic. De Fontenay denounces what she calls the dangerous thoughtlessness of animal liberationists.

She raises the issue of a possible "levelling down" of human beings when she accuses Singer of suggesting that infants and the severely handicapped should be treated like animals. She herself acknowledges, though indirectly, that she has misinterpreted him. Singer on the contrary advocates a "levelling up", as evidenced in the following quote from Pratical Ethics:

I do not wish to suggest that intellectually disabled humans should be force-fed with food colourings until half of them die [...]. I would like our conviction that it would be wrong to treat intellectually disabled humans in this way to be transferred to nonhuman animals at similar levels of self-consciousness and with similar capacities for suffering. (1993: 78)

De Fontenay clearly opposes the rationale Singer derives form the marginal cases and particularly the new categories he creates: indeed he replaces the traditional differentiation between animals and humans by a new one between person and non person. A person is defined as possessing self-awareness, autonomy, and a capacity to feel pleasure and pain, as well as a sense of the future. This does not apply to comatose patients, newborn children, the severely handicapped that consequently are not persons, whereas animals such as apes, dolphins and other superior mammals can be categorized as persons.

This is the line of thought that de Fontenay rejects, recalling that continental philosophy is built on the opposition between humankind and animality and that the natural rights philosophy derives from some transcendental, immanent power. She finds the marginal cases argument particularly offensive because our whole culture and history tell us that any human being is special. She accuses Singer of "misanthropy"(2000: 146). She has harsh words about him: : "I am only pointing to the fact that the utilitarian approach to good and evil is an offence to mankind [...] and I do not 
think that the best way to open men's heart is to offend it" (2000: 145). She writes further:

It is foremost a question of style and method. The empiricist and logicist reasoning, the lack of consideration and misanthropy of such writers [as Singer and Cavalieri] make me sad, for such a confidence in deduction, or even syllogism, and in some decision-making casuistic power prevents basic pedagogy from coming into play. But without the art of persuasion, animals' friends and advocates are unable to share their demands. (de Fontenay 2000, 146)

The conclusion to be drawn is that de Fontenay's line of reasoning appears to be more convincing and philosophically relevant way than Ferry's. But it is unfair to write that Singer's style prevents basic pedagogy from coming into play. The influence of Animal Liberation proves that, on the contrary, his straightforward utilitarian demonstration acted as a solid foundation for the demands of many animal advocates. De Fontenay raises important questions, though, when she identifies the problems of Singer's position on the severely handicapped which have led to conflicts with organisations for the disabled. What must be underlined is that he draws our attention to painful issues that must be solved. This is probably why we find some of his solutions offensive.

Other ethical changes, other forms of resistance come from our next field of study: the Christian response to Singer's apparent disregard for the sanctity of human life.

\section{The Christian Response}

In Rethinking Life and Death, Singer calls our traditional ethic a "farce" and an "endlessly repeated tragedy." He adds that it is "defended by bishops and conservative bioethicists who speak in reverent tones about the intrinsic value of all human life, irrespective of its nature or quality" (1994: 3). The thinker Paul Valadier falls into this category.

\subsection{Paul Valadier: ${ }^{4}$ Does Abolishing Suffering Mean Abolishing the Sufferer?}

In 2006 Paul Valadier gave a talk entitled "Disrupted Morals" in which he tackled the question of utilitarianism, especially Singer's, and its influence in the making of contemporary ethical attitudes.

Though in France utilitarianism is at best derided, and more often simply given short shrift, Valadier considers it to be the dominant philosophy of our day and age. He argues that it is an appealing and generous doctrine at first glance, which however turns out to be alarming on closer scrutiny. He argues that our time is paradoxical and that utilitarianism combines with individualism 
to undermine our traditional concept of human dignity. "Disputed Morals" offers a summary of Valadier's views on, and objections to, utilitarianism, as well as contains his position on ethics that may be summed up as follows:

1. The visibility of evil gives the feeling that it is more prevalent than good in our moral world.

2. Individualism and utilitarianism are potentially destructive of our traditional references such as justice, solidarity, respect and dignity.

3. Kant was right in his categorical imperative: we have to respect humanity and recognize the universal law that all human beings possess dignity as a given.

Valadier takes issue with utilitarianism on the question of suffering. He understands utilitarians want to reduce or even eliminate it, even if this entails euthanasia:

If dignity is related to a person's memory, reason, capacity to communicate and to have a sense of the future, Singer believes that a severely handicapped person, deprived of these characteristics, has lost dignity. So there is no reason to keep this person alive. Singer goes further. He argues that some humans are not persons, while some animals are, since they are dignified. (2006)

Two questions emerge: 1. Should one focus on abolishing suffering? 2. Does it not mean one might abolish the sufferer, as Nietzsche pointed out?

My view is that there are two limits to Valadier's reading of Singer. First, Valadier neither defines the concept of human dignity nor explains what is meant exactly by its loss. What is more Singer never uses the concept, referring rather to "characteristics" and "interests." Second, Valadier fails to mention that Singer uses the category "person" in a precise sense, not in the commonly accepted sense, which changes the tenor of Singer's line of reasoning.

Valadier strongly reject utilitarianism. As Singer rightly claimed in Rethinking Life and Death, there is a force for conservatism in ethics based on ill-defined traditional notions such as dignity, humanity, or personhood which are bound to clash with newly emerging ethical attitudes. Singer does not "abolish the sufferer". On the contrary, his view is that the interests and preferences of the sufferer should be considered.

The last group — French animal liberation theorists - provide a better appraisal of Singer's views, as will be shown below.

\section{The French Animal Liberation Movement}

Though the status of animals has received less attention in France than in English speaking 
countries animal liberation organisations abound, chief among which Les Cahiers Antispécistes ${ }^{5}$ which shares some of Singer's ideas since it rejects "speciesism," that is to say discrimination based on species. The first of two major theorists writing for the Cahiers and taking issue with Singer's views is Yves Bonnardel. His views will be presented and assessed followed by Estiva Reus's.

\subsection{Yves Bonnardel ${ }^{6}$ and Singer's Legacy}

In "Humanism, and then what?" ("L'humanisme, et après ?" 2006), Bonnardel develops his views on Singer's contribution to animal liberation and on what a human being is. He points out a common misinterpretation of the term utilitarian in France by clearly marking the difference between

1. Utilitaire: (usually derogative) which means designed to be useful rather than attractive; preoccupied by material interests.

2. Utilitariste: based on the idea that the morally correct course of action is the one that produces benefit for the greatest number of people.

The second meaning is the only relevant one when talking of Singer.

Bonnardel views Singer as instrumental in deconstructing the myth that our species only is worthy of consideration. He fittingly opposes mainstream humanist morality to the consequentialist egalitarianism suggested by utilitarians. The belief that most humanists hold results in the idea that the natural difference between humans and other animals justifies a difference of treatment, and that only humans possess awareness, reason, freedom and intelligence, tenets that Singer and other philosophers (such as Tom Regan, James Rachels, Paola Cavalieri, Estiva Reus), systematically criticize and hold to be:

1. Unclear, because awareness, freedom or intelligence are rarely defined.

2. Elitist, in that they tend to exclude humans that do not fit the description.

3. Irrelevant, in that they favour individuals that possess those qualities.

The yardstick for Singer's "equal consideration of interests" is sentience, which means that all sentient beings deserve to be included in our moral world. The immediate consequence of this is that the lives of all vertebrates, fish included, should be taken into account because they have an interest in not suffering.

Bonnardel is the one that offers the only positive assessment of Singer's views so far. He uses the concepts of Nature and domination more extensively than Singer does. For instance Bonnardel claims that discrimination against animals is based on their belonging to a "natural" (his inverted commas) category different from humans' and that this argument is just an ideological 
excuse used by humans to dominate them, invoking what he calls the "God Nature" (2006). Singer does not speak in such terms, nor does he insists, as Bonnardel does, on the similarities between speciesism, racism and sexism. Yet, his definition of utilitarianism is to the point. His contribution to the debate is also significant in that he emphasizes a major element in Singer's thought: the idea that any departure from the requirement of equality which is not based on relevant criteria is arbitrary and unfair.

Our next and final thinker, Reus also presents Singer in a favourable light, taking issue with what he has to say on sexual relations with animals.

\subsection{Estiva Reus:" About Singer's "Heavy Petting"}

In 2001, Singer published a review for Midas Dekker's book Dearest Pet. In this text entitled "Heavy Petting" Singer deals with the ultimate sexual taboo: bestiality, or sexual relationships between humans and animals. He explains that though many taboos (on contraception, sex toys, masturbation or sodomy) have fallen, the fact that bestiality is still strongly prohibited reflects our ambivalence about animals. Two years after the publication of this highly controversial article, Estiva Reus comes back on the reactions that Singer's views inspired. Her thesis is that many in the animal movement itself would have preferred Singer to remain silent on this issue.

Reus expresses surprise at the violence of the reactions to what is an analytical text. Singer does not give his opinion on the "normal" or "natural" character of bestiality in "Heavy Petting." It is not a normative stand in favour of these acts. Singer considers that the only reason why the taboo remains is that such acts constitute in people's minds "an offence to our status [...] as human beings" (2001). He only proscribes cruel sexual activities with animals, whereas his critics (Gary Francione in the lead) believe that all bestiality is morally reprehensible. Reus believes Singer's position on the issue met such fierce opposition because it offends the humanist view that only humans are supposed to be "free," to act creatively, to perform gratuitous sexual acts, animal sexuality being deemed to be purely functional. Apart notably from Ingrid Newkirk, the president of the major animal rights organisation People for the Ethical Treatment of Animals, this view is generally shared by proponents of the animal movement. Many of them underline the gap between the human order and the natural/animal order. As Reus puts it: "[Singer's adversaries] get angry because he hurts their representation of the order of things. They claim they are talking the world as it is. They are actually talking of the world as they would like it to be" (2002).

Reus's contribution is interesting as it shows that the opposition to Singer's view on bestiality is not so much philosophical and ethical as it is emotional. 


\section{Conclusion}

I have examined a wide range of thinkers belonging to three different schools: the humanist, Kantian school, the Christian school, and animal liberation school of thought. The traditional thinkers that unconditionally support the sanctity of human life (Ferry, de Fontenay and Valadier) reject Singer's advocacy of the equal consideration of interests based on sentience, while Bonnardel and Reus defend Singer's position.

My conclusion at this point would be that Singer has, to a certain extent, been misread in France. He does not deny the specificity of human life or cheapen human life. On infanticide for example his position is not that parents should always terminate the life of their severely disabled child, but that they should have the right to do so. ${ }^{8}$ As for disabled people, he wants them to have a right to choose euthanasia if their suffering warrants it. One may not agree with this, but if one objects even strongly it does not mean his views can and deserve to be caricatured and distorted.

It must be added that Singer's views do inspire strong adverse reactions, even when appropriately read and analysed. The arguments of de Fontenay (on the utilitarian method), Valadier (on the failure to appreciate the importance of the individual) prove that his positions are sometimes judged not by the extent to which they clash with accepted moral views, but on the basis of the criteria which he uses to make his point.

Given that our society finds itself on the threshold of a major ethical transformation, at a juncture when the potential exists for a novel moral outlook (that would be more coherent and relevant), given that it is faced with extremely concrete and real moral dilemmas, which arouse many questions as well as uneasiness, we need Singer's contribution to the degree that he reformulates these problems and offers a way of addressing them, if not actually solving them. Some of the reactions to his theories expressed in France reveal a genuine opposition to his conclusions. Many also show how uncomfortable some of us are when facing contemporary ethical problems and confronting those who dare to address them. This may help explain why, to borrow from Shakespeare, being the bringer of uncomfortable news, Singer partly has "but a losing office" in France. 


\section{Notes}

${ }^{1}$ Luc Ferry is a professor of philosophy. He is specialised in the work of Kant, which he translated in the prestigious French collection La Pléiade. He was Education Secretary under the Chirac administration from 2002 to 2004.

${ }^{2}$ Élisabeth de Fontenay is a French scholar and essayist. She is emeritus professor of philosophy at the Sorbonne. She has written extensively on animals for twenty years.

${ }^{3}$ 2008. Sans offenser le genre humain. Réflexions sur la cause animale, Paris: Albin Michel.

${ }^{4}$ Paul Valadier is a philosopher and theologian. Professor emeritus at the Facultés Jésuites de Paris, he wrote several books and articles on Nietzsche, politics, religion, ethics and the Christian faith.

${ }^{5}$ The journal was founded in 1994.

${ }^{6}$ Yves Bonnardel is a philosopher. He is interested in the concepts of domination and appropriation based on Nature, species, gender or skin colour.

${ }^{7}$ Estiva Reus is an academic and a member of the editorial board of the Cahiers Antispécistes. She works on questions pertaining to the status of animals as well as on strategies for improving their condition.

${ }^{8}$ Further in the same article, he adds that his interest in life and death ethics was first motivated by a desire to defend parents' rights. He felt then that doctors took advantage of their power, sometimes out of a sheer personal ambition, and decided to maintain a newborn child or a comatose patient alive, against their families' will. Singer is not motivated by eugenics, nor by a will to stop the progress of medicine. 


\section{References}

BONNARDEL, Y. 2006. L'humanisme, et après ? Jibrile 6. < $\underline{\text { http://www.revuejibrile.com/JIBRILE/PDF/ }}$ HUMANISME.pdf $>$

CAVALIERI, P. 2000. “L’humanité au-delà des humains,” Le Débat, 108: 84-192.

DE FONTENAY, É. 2000. Pourquoi les animaux n'auraient-ils pas droit à un droit des animaux ? Le Débat 109: 138-155.

FERRY, L. 2000. Des «droits de l'homme» pour les grands singes? Non, mais des devoirs envers eux, sans nul doute. Le Débat 108: 163-167.

REUS, E. 2002. Lyncher pour ne pas être lynché ? Réflexions sur les réactions suscitées par «Heavy Petting» de Singer. Les Cahiers antispécistes 22. $<$ http://www.cahiers-antispecistes.org/spip.php?article202> SINGER, P. 1993 [1979].Practical Ethics, Cambridge: Cambridge University Press.

, 1994. Rethinking Life and Death. The Collapse of our Traditional Ethics, New York: St Martin's Press.

, 2000. Interview with Stéphanie Ruphy. Peter Singer: l'éthique revisitée. La recherche 335:

109-111.

, 2001. Heavy Petting. Nerve. http://www.nerve.com/opinions/singer/heavypetting/main.asp

VALADIER, P. 2006. Morale en désordre. Conference given at the Halle au Blé in Altkirch, October, 13. $<$ http://www.pacariane.com/CCCSundgau/Conferences/061013cr.html> 